\title{
SOCIOLOGY VERSUS IDEOLOGY IN COMMUNIST ROMANIA: SOCIOLOGY'S RE-EMERGENCE AND ROLE
}

Stefan Bosomitu

Institute for the Investigation of Communist Crimes

and the Memory of the Romanian Exile, Bucharest

By the end of the Second World War, Romanian sociology was an academic discipline with a distinguished tradition. It was hoping to obtain international recognition during the 1939 International Sociological Congress, which was scheduled to take place in Bucharest, but the outbreak of the Second World War annulled what was supposed to be Romanian sociology's "finest hour." Interwar Romanian sociology was to a certain degree synonymous with its most important figure, Dimitrie Gusti, who was also the founder of the Bucharest Sociological School (the "Monographic School"), a scholarly infrastructure built around an impressive institutional network. Dimitrie Gusti became the chair of the Sociology Department of the University of Bucharest just after the end of the First World War, and subsequently initiated several projects that led to the institutionalisation of sociology in Romania. He was the founder and manager of various institutions: the Association of Science and Social Reform (1919-1921), the Romanian Social Institute (1921-1939, 1944-1948), the Romanian Institute of Social Sciences (1939-1944), and the Village Museum (founded in 1936). He also initiated the publication of several periodicals: the Archive for Science and Social Reform (1919-1943), and Romanian Sociology (1936-1944). Gusti and his "school" focused on monographic rural studies, and initiated intensive research into Romanian villages. The main purpose was to implement an extensive project of modernising Romanian society through social intervention, community development, and social engineering. Gusti's project was extensively supported and financed by the state authorities, 
through the Prince Carol Royal Cultural Foundation, which Gusti managed from 1934 on. Gusti’s school brought together important intellectuals of the time and its most outstanding figures were Henri H. Stahl, Traian Herseni, Mircea Vulcănescu, and Anton Golopenția.

The post-war geopolitical arrangements put Romania within the Soviet sphere of influence, a factor that determined the country's subsequent evolution. The Soviets favoured the uninfluential Romanian Communist Party, a small organisation which had been outlawed in the previous two decades. Within a couple of years, the communists had managed to gain full political control: by 1945 they were already dominating the Council of Ministers; in 1946 they won the elections (which were grossly falsified); and in 1947 they forced King Michael I to abdicate and instituted the Popular Republic.

After the establishment of a Soviet-type communist regime in Romania, sociology was labelled "bourgeois" and subsequently banned. Political repression and the ideological inflexibility of the communist regime delayed the re-institutionalisation of the discipline for almost two decades. It was only rehabilitated in the early 1960s when a fortunate and supportive political and ideological context allowed it to re-emerge and separate itself from the other social sciences. My paper will discuss not only the institutional articulation of the re-emerging discipline, but mainly how sociology was re-imagined and re-contextualised as a discipline expected to provide the data and means for a new cycle of modernisation. The role that the political regime intended to assign to sociology - as a science in charge of "technical social modernisation" (Cotoi 2011: 142) - is revealed by an overview of Romanian sociology's major themes during the socialist period, and will also be considered. In order to better understand the role sociology was assigned within communist society, it is important to ask a few questions: on what theoretical framework did sociology re-emerge in the early 1960s? To what extent did sociology manage to individualise itself in relation to the official ideology, and especially in relation to historical and dialectical materialism? What role did the political power assign to sociology, and what were sociology's main functions and/or purposes?

\section{/// Post-war Eastern European Sociologies: The Historical Context}

The establishment of communist regimes within the countries that entered the Soviet sphere of influence conditioned the post-war history of social sciences in Central and Eastern Europe. From a general survey of the sub- 
ject, it is easy to ascertain a similar pattern in all these cases. The annulment of the previous aggregated forms of the discipline - especially in the countries with an important tradition in the field (i.e., Poland, Czechoslovakia, and Romania), was a common, similar, and unitary phenomenon. The political power's first step was a general denunciation of the "old structures." The next focused on institutions and individuals. The main purposes of this strategy relate to the newly established regime's need for control, but also to the desire to institute Marxism-Leninism as the only legitimate ideology (Mespoulet 2017: 3). Everything that existed outside the accepted canons of dialectical and historical materialism was frequently labelled bourgeois and reactionary, and subsequently censured or banned (Szamta \& Wysienska 2000: 2116-2123). Like the other social sciences, sociology was unconditionally affected. Perceived as a "bourgeois pseudo-science" or even a "reactionary science," sociology was removed from the academic field and curricula (Keen \& Mucha 1994: 6), the research infrastructure was dismantled, and the professionals of the discipline were compelled to "migrate" towards other fields, mainly anthropology, folklore, and statistics. The ideological dogmatism and the implicit immobility diminished in the next decade, particularly during the Khrushchev thaw (Weinberg 2004: 11; Zemtsov 1986: 3-4). Several important changes occurred. The most important involved the term itself. "Sociology" left the dictionary of taboo words and was accepted both in academic and political discourse. The "bourgeois pseudo-science of society" became "bourgeois sociology"; the Soviet Union and its satellite states responded with Marxist sociology (Batygin \& Deviatko 1994: 14-15), which was infrequently confused, at least initially, with historical materialism. Other advances led to a resumption of academic contacts with the West, and the participation of Eastern European scholars in international debates and institution-building (Shalin 1978: 173). Although strictly monitored by the political power, this global, cross-border dialogue was an important step in the development of sociology in Eastern Europe.

The subsequent evolutions of sociology in the Soviet Bloc countries followed a specific pattern: the emergence of a national professional organisation, the establishment of the first university departments or research centres, and the appearance of specialised periodicals (Voř́šek 2008: 9091). The re-institutionalisation of sociology was determined by several circumstances, both internal and external. The process that led to the revival of the discipline was confronted with various initiatives and actors, but each and every time the political power was the one that approved and 
"validated" the re- institutionalisation (Vorríšek 2008: 91). It is important to note that the revival of sociology seems to have been a common phenomenon among these countries, despite their differences, that is, their distinct historical pasts, heterogeneous traditions as regards sociological research, and divergences in intellectual trends (Wiatr 1971: 1-19). Nonetheless, the process was neither unitary, nor simultaneous. There were different stages in the evolution of sociology, with the causes behind these differences being related either to certain previous intellectual traditions, or to the inconsistency and reluctance of the political regimes (Sztompka 2004: 159-174).

\section{/// Continuity or Rupture in Post-war Romanian Sociology?}

A debate initiated by the review Sociologie românească [Romanian Sociology] in their first issue of 2005 gives an accurate idea of how the history of Romanian sociology under socialism is currently perceived by the professionals of the discipline. In an interview, under the heading "Rupture and/ or Theoretical-Methodological Continuity between Pre-war Sociology and Sociology in the Communist Period: The Status of the Marxist-Leninist Paradigm; Defensive Strategies of Sociology," pressed opinions that summarised the issue (Buzărnescu et al. 2005: 5-37).

One of the interviewees stated that there was a clear rupture between interwar and post-war sociology and that the rupture was particularly visible in the first decade after the communist regime came to power, when sociology was "creatively denied." However, he also asserted that there was a kind of continuity between the two, as exemplified by the destinies of Henri H. Stahl or Traian Herseni, interwar sociologists who resumed their activity in the communist period. Moreover, another phenomenon that would confirm the "continuity" was represented by the (monographic) field research that was being conducted even when sociology was banned. Despite being subsumed to other purposes, these enquiries sought the verification of scientific hypotheses. The same author further argued that there had been no Marxist-Leninist paradigm in Romanian sociology under socialism, as no professional had seriously adopted such an outlook. Another interviewee asserted that the establishment of communism led to an obvious rupture in sociology, a science with a "critical vocation," since historical materialism, conceived as a "dogmatic and simplistic version of Marxism," was substituted for sociological analysis. The same interviewee also suggested that the influence of interwar Romanian sociology (and es-

\footnotetext{
1 All the quotations in this paper have been translated into English by the author.
} 
pecially of the Bucharest Sociological School) on post-war sociology was conspicuous, particularly after 1965. The other opinions expressed seemed to suggest the same perspective as regards Romanian sociology in the aftermath of the Second World War. The year 1948 was labelled the point of an obvious break, marked by the dissolution of university departments and specialised research facilities. Nonetheless, the existence of a connection that signalled continuity between interwar and post-war Romanian sociology was firmly asserted. The "durability" of the discipline was ensured by the "tradition of monographic research," which was preserved and perpetuated, even if it was undertaken under the "scientific umbrella" of other disciplines: philosophy, statistics, economics, and geography.

The main ideas expressed in the above debate summarise a general trend in Central and Eastern European countries that attempts to identify and associate the epistemic framework of national sociologies within autochthonous intellectual traditions. In the Romanian case, the continuity between interwar and post-war Romanian sociology is rather a postsocialist narrative, even if the topic was also discussed and disputed at the time, as will be explained later. Other important factors of the post-war "rupture" were also overlooked. The controversial rapports between interwar sociology (mainly the Bucharest Sociological School) and the political power (Momoc 2012), the allegiance of several sociologists to the Iron Guard (a far-right/fascist Romanian interwar movement) ${ }^{2}$ (Boia 2011: 158; Momoc 2012: 248-288), and the active involvement of several other sociologists in the authoritarian regimes in Romania during the Second World War (Boia 2011: 235, 312) were insufficiently addressed.

\section{/// A Controlled Re-institutionalisation of Sociology (1959-1977)}

A descriptive history of the re-institutionalisation of sociology in communist Romania can be easily compiled. In May 1959, the National Sociological Committee (NSC) was established (T.B. 1962: 225). The same year, the NSC was affiliated to the International Sociological Association (ISA), and a Romanian delegation participated at the IV International Congress of

\footnotetext{
2 The Bucharest Sociological School gathered intellectuals with diverse political backgrounds: Henri H. Stahl, Gheorghe Vladescu-Răcoasa, and Mihail Pop were known for their sympathy for the Left; Miron Constantinescu was a member of the clandestine Communist Party; Dumitru C. Amzăr, Ernest Bernea, and Traian Herseni were members and doctrinaires of the Iron Guard (an interwar Romanian Fascist movement). While Dumitru C. Amzăr chose exile after the end of the Second World War (refusing to return to Romania while occupying an office at the Romanian Legation in Berlin), Ernest Bernea and Traian Herseni were imprisoned for their prior political convictions by the Communist authorities.
} 
Sociology, organised in Milan and Stresa (Italy) (T.B. 1962: 226). Several years later, in 1963, after almost fifteen years of absence, a specialised periodical, The Romanian Journal of Sociology, was published by the NSC. Furthermore, in 1965 the Centre for Sociological Research, subordinated to the Romanian Academy, was established (Constantinescu 1970: 11). The same year, the General Secretary of the Romanian Communist Party, Nicolae Ceaussescu, ${ }^{3}$ acknowledged the importance of sociology and the subsequent necessity to reconsider it, in a speech that guaranteed its renewal. In the following years, departments of sociology were founded within the major Romanian universities in Bucharest, Iasi, and Cluj (Costea et al. 2006: 367). In addition, several other research facilities, specialised institutions, and sociological laboratories were initiated in the following years (Constantinescu et al. 1974: 172-180).

Besides these factual details, in order to comprehensively understand the re-institutionalisation process, important issues and questions need to be addressed. First, the establishment of the NSC was not a private (individual or collective) initiative, but an assignment the regime commissioned to several high-ranking officials or representatives in the social sciences. ${ }^{4}$ The active interference of the political decision-makers entailed unreasonable control over the scientific framework of the new discipline and consequently altered it. Thus, the "new" sociology emerged as a "captive" science, imposed by the regime. Moreover, the representatives commissioned for the assignment had only limited or peripheral association with sociology (an exception was Tudor Bugnariu, a Marxist philosopher with a bachelor's degree in sociology) (1933) (Bosomitu 2015: 341). Romanian delegations (generally including the same officials of the NSC) participated in the ISA international congresses in 1959 (Milan and Stresa) and 1962 (Washington, D.C.), but aside from its activities abroad, the NSC advanced no clear plan or programme for a complete institutionalisation of the dis-

\footnotetext{
${ }^{3}$ Nicolae Ceaușescu (1918-1989), at one time an apprentice shoemaker, he became a member of the clandestine Communist movement at the age of fourteen, being arrested and imprisoned several times during the interwar period. In the post-war years, he occupied influential offices within the party and state structures. After the death of Gheorghe Gheorghiu-Dej, general secretary of the Romanian Communist Party (1945-1965), he was elected by the Central Committee to be his successor. In 1974, he instituted the office of President of the Republic, to which he was elected every five years until his death. He was overthrown by a huge popular uprising in December 1989. Arrested, he was indicted in a summary trial on 25 December 1989, sentenced to death, and executed the same day.

${ }^{4}$ National Archives of Romania (NAR), Council of Ministers fonds, section Athanase Joja Cabinet, file 15/1959, p. 6: "Address from the Central Committee's Internal Affairs Section."
} 
cipline. ${ }^{5}$ In the early 1960s the NSC officials acted mainly as "diplomats," assigned to an ideological rather than a scientific mission (Constantinescu 1972: 9-10; Rostas \& Stahl 2000: 170), and seemed to have no interest in the further development of sociology beyond the current structures. Still, the existence of the Committee permitted a cautious and controlled acceptance and receptiveness towards sociology, and indirectly influenced the subsequent evolution of the discipline. Another important element in this process was external pressure (the advancements made in the field by the other socialist countries). In 1963, officials of the Central Committee's Science and Art Section discussed and accentuated the Romanian Academy's non-performance in fields where other socialist academies (mainly the Soviet and Polish academies of sciences) had significantly progressed - the case of "concrete sociology" was emphasised. ${ }^{6}$ Due to this specific situation, several initiatives that aimed at a further institutionalisation of sociology were authorised (Rostas \& Stahl 2000: 164-165). While the regime made the first steps toward renewal of the discipline, the subsequent initiatives emerged from below - several academics or academic networks concurring that a "blind spot" had appeared in the social sciences field. Tudor Bugnariu, dean of the Faculty of Philosophy of the University of Bucharest was in charge of one of these initiatives. His inability to negotiate successfully between the political decision-makers and academia led to the interruption and later annulment of his project. In these circumstances, other initiatives surfaced to take advantage of the same opportunity. All were revoked by the return to power of Miron Constantinescu, a Marxist intellectual, senior Communist Party member, and former associate of the Bucharest Sociological School, who assumed dominance over the discipline. Imprisoned during the Second World War for communist activism, Constantinescu became an important member of the Communist Party leadership, occupying influential offices during the first post-war decade. He was later purged and removed from office, after a putsch attempt in 1956. Marginalised by Gheorghiu-Dej's regime - a situation that allowed him to resume his academic career - Constantinescu was to be rehabilitated by Nicolae Ceauşescu after 1965, regaining an important political position (Bosomitu 2015). Constantinescu became the promoter and protector of the "new" sociology (Zamfir 2009), mediating the complex rela-

\footnotetext{
${ }^{5}$ NAR, Council of Ministers fonds, section Athanase Joja Cabinet, file 15/1959, pp. 7-8: "Statute of the People's Republic of Romania National Sociological Committee."

${ }^{6}$ NAR, Central Committee of the Romanian Communist Party fonds, Agitprop section, file 9/1963, pp. 35-37: "Protocol of the Central Committee's Science and Art Section Meeting (November 4, 1963)."
} 
tion between it and the regime's decision-makers, while his political status gave the discipline precedence over the other social sciences (Kolaja 1974: 78; Tismaneanu 2004: 159-160).

The subsequent evolution of sociology in Romania was marked by several events which led to its being marginalised again. In 1970, the Academy of Social and Political Sciences was established in direct subordination to the RCP's Central Committee and assimilated the Romanian Academy's prerogatives and infrastructure in the social sciences field (Buletinul Oficial: 130). This evolution sealed the communist regime's control over the social sciences. One year later, Romania's cultural policies were subjected to a major ideological reorientation, including with the launch of Nicolae Ceauşescu's famous "July Theses" - a mini “Cultural Revolution" that implied the return of dogmatism, conformity, and the dismissal of every attempt at autonomy (Verdery 1991: 107, 113). Moreover, the untimely death of Miron Constantinescu (1974) deprived sociology of his support and influence among party officials and decision-making bodies (Mihailescu \& Rostas 2007: 91). It was the start of a gradual decline. In the following years, the research infrastructure was dismantled, and in 1977 the study of sociology was restricted to postgraduate curricula (Costea et al. 2006: 368). All the university departments of sociology and sociological research facilities were disbanded, and after 1977 the only institution that included sociology in its curricula was the Ștefan Gheorghiu Academy of Social and Political Studies - the party academy, which was directly subordinate to the Romanian Communist Party Central Committee.

\section{/// What Kind of Sociology Did Communist Romania Have?}

By the late 1960s, sociology was a fully institutionalised academic discipline in Romania - with a professional association, departments in the major universities, an important research infrastructure (research institutes, laboratories), and several specialised periodicals. The first department of sociology was established in 1966, in the Faculty of Philosophy of the University of Bucharest. Similar departments were founded a year later at the Babes-Bolyai University of Cluj and Alexandru Ion Cuza University of Iasi. Research laboratories, subordinate to these departments, were founded: in 1966 at the University of Bucharest, in 1968 at the University of Cluj (Kallós \& Roth 1970: 123-125) and University of Timisoara, and a year later at the University of Iasi (Bărbat 1970: 127-129). Several others research facilities were subordinated to the Romanian Academy (Cernea 1970: 45-62), and 
others were even established outside the academic field, such as the Research Centre for Youth Problems, a government agency founded in 1968 and subordinated to the Ministry of Youth Affairs (Bădina 1970a: 63-71, 1970b: 97-108; Schifirneț 1999: 137-142).

Aside from this institutional articulation of the discipline, it is important to explain the ideological restrictions and conditions under which the social sciences in general, and sociology in particular, developed in communist Romania. Furthermore, it is necessary to discuss the role that the political regime intended to assign to sociology as a science in charge of "technical social modernisation" (Cotoi 2011: 142), the theoretical and ideological premises the "new society" was to be built upon, and how everyday practices challenged these theses.

The first important issue to be addressed refers to the "paternity" of the new Romanian sociology. As previously mentioned, the post-socialist narratives linked the renewed discipline with its interwar traditions, but the "connection" was rejected at the time (Constantinescu 1971: 209). Re-emergent Romanian sociology tried to individualise itself by appealing to autochthonous intellectual traditions. But these "traditions" never referred exclusively to the intellectual project sponsored by Dimitrie Gusti (of the Bucharest Sociological School) but rather to other preeminent intellectual figures considered to have forged some kind of "Romanian social thinking." This category included Dimitrie Cantemir, Nicolae Bălcescu, Theodor Diamant, Lucrețiu Pătrășcanu, and so forth (Constantinescu et al. 1974). A possible link between post-1965 and interwar sociology was frequently dismissed, as the Bucharest Sociological School (and its theoretical framework) was considered to be "idealistic and eclectic." Therefore, "it never resisted the confrontation with social reality," and thus it was continuously "diluted, until it fell apart" (Constantinescu 1971: 208210). Still, one relevant exception, which was to inspire the post-socialist narratives, must be mentioned. A programmatic article signed by Tudor Bugnariu (dean of the Faculty of Philosophy, University of Bucharest) and Traian Herseni (an important former member of the Bucharest Sociological School) advocated the reclamation of interwar traditions in sociology. Although the authors acknowledged the interwar sociology to have been "idealistic," "unscientific," and "obsolete," they also claimed that some of the techniques and methods it had employed could and should be reconsidered. Moreover, the two authors alleged that the "tradition of monographic research" (which was characteristic of interwar sociology), had never been lost, but had evolved during the years of assimilating Marxist 
methodology (Bugnariu \& Herseni 1964: 7). The thesis advanced by Bugnariu and Herseni was part of a more complex programme that considered a re-launch of sociological research in Romania - which was never accomplished, as previously mentioned. Still, a certain connection or continuity should be acknowledged, mainly in terms of personnel and its flow between the two periods. Even if the majority of the former sociologists were never rehabilitated, or recuperated, by the "new" discipline, some were part of the new project (i.e., Henri H. Stahl, Traian Herseni, Mihai Pop, Vasile Caramelea, etc.), even if they were never to acquire pre-eminent positions.

Another point of this discussion should refer to the degree of autonomy of sociology in relation to the official ideology in general, and historical materialism in particular. There are several hypotheses related to this issue. One suggests that there were no differences between Eastern European sociology and historical materialism, the two terms being synonymous, both referring to the same science about society. Another hypothesis maintained that historical materialism and sociology are two different concepts. The first concept refers to the theoretical and philosophical analysis of society, while the second to empirical investigation and generalisations based on this type of investigation. Finally, a third way would be defined by the idea that historical materialism overlapped sociology as it assimilates the results of empirical sociological research. In this case, it was admitted that historical materialism was more general than sociology because it included sociology; historical materialism was using the facts and conclusions set forth by sociological investigations (Wiatr 1971: 1-19). The Romanian case seems to fall into the second category. In official discourse, the re-emerged Romanian sociology was considered to be closely related to Marxist philosophy - defined as "a binomial unit composed of historical materialism and dialectical materialism." This "Marxist philosophy" was to act as a guide (or standard) not only to sociology but also for all the social sciences. Thus, sociology was not to be mistaken for historical materialism - a trend that was considered "ineffective, and even responsible for the impasse the discipline failed to overcome in the past decades" - but as subordinate to historical materialism, which had its precise role as "theoretical and methodological guide." Moreover, sociology was considered to have an "applicative" character as "its research results may constantly enrich the theory of historical materialism, and serve the political sciences, and scientific socialism" (Constantinescu 1971: 212). This way of defining the discipline may have decisively influenced its technical character during the communist regime (Cotoi 2011: 143-144) - as sociologists focused espe- 
cially on empirical investigations, and only formally accepted the Marxist canons. But some authors occasionally challenged this official narrative, as no significant difference was to be perceived between the curricula of historical materialism and sociology (Rostas \& Stahl 2000: 167).

A third point of our discussion should refer to the role assigned to sociology in communist society. Addressing this issue, we have to indicate the difference between the official discourse and reality. The official discourse imagined sociology as tri-functional. Aside from the purpose of the discipline, which was defined by its principal functions - the scientific and the critical - sociology was also imagined as capable of developing itself towards social-engineering projects (Mihăilescu \& Rostas 2007: 56) - an idea which assigned sociology a third and fourth function, that is, a prospective and prognostic one:

Sociology is the science that examines the totality of social relations between people and their developments, the actions and the social struggles, but also the social structures and social processes in their development; the aim of this survey is to discover the inner, inherent, and essential correlations between social facts, the constant and essential connections between phenomena, that enables the discovery of regularities and social laws. Discovering the laws of society, or of the social-economic structure, allows making assumptions, and prerequisites for predictions of social development. Therefore, sociology is not only a descriptive and analytical science, but also prospective and prognostic. Sociology elaborates predictions and prognoses (Constantinescu 1971: 275-276).

Despite this desideratum, the reality was quite different. Even if the majority of the discipline's new professionals were provided with scholarships and study trips abroad, to France, Belgium, Austria, or the United States (Bosomitu 2015: 346; Zamfir 2005: 57), connections with the newest trends in international sociology were at a low level. In essence, Romanian sociology remained to a degree reminiscent of the obsolete way of perceiving and defining the discipline - that is, understood rather in terms of a social philosophy and not as being able to develop into social engineering. Moreover, there are more palpable proofs that contradict the official discourse. The discipline regularly emphasised the component of social knowledge and the "objective analysis of social problems." Essentially, the curricula were designed to train sociologists (with a major focus 
on the philosophical field) and not social engineers (Mihăilescu \& Rostas 2007: 56; Rostas \& Stahl 2000: 167). Still, as the theoretical framework of the "new" sociology indicated, the state extensively sponsored studies and research in order to evaluate and comprehend the "new society." Sociology was imagined as an instrument to serve the regime's desire for scientific knowledge. Thus, these studies' main purpose was not necessarily to reveal societal dysfunctions, but rather to challenge the dysfunctions, with the end of offering solutions for overcoming them. But the solutions provided by sociological surveys - when (and if) requested - were frequently acknowledged with extreme caution, and even with suspicion by the decisionmakers, who often doubted their benefit. Due to this situation, and to the intricate process that led to sociology's re-institutionalisation (which was, after all, a negotiation between the initial, top-down political programme and the subsequent academic ones that emerged from below), sociology never managed to evolve into a "critical" discourse. A notable exception in this regard is the Law on Global Agreement. Before being promulgated in 1974, the law was used in a year-long social experiment in which it was tested and submitted to thorough sociological analysis in several industrial units in order to predict the effects it might produce (Mihăilescu \& Rostas 2007: 53-54).

\section{/// Romanian Sociology's Main Research Themes}

The re-institutionalisation of sociology was not an independent phenomenon. It was largely determined by political will but also by the needs of the regime: "The reorganisation and improvement of sociological education, studies, and research is a necessity derived from the actual requirements of socialist society, and the need for a complete and multilateral knowledge of socialist reality" (Constantinescu 1971: 223).

Romanian society underwent massive reconfiguration (both economical and societal) during the first two decades of communist rule: industrialisation and urbanisation; collectivisation of agriculture; massive migration of population from rural to urban areas; and restructuring of cultural and educational systems. All these changes caused significant changes at a societal level, the appearance of new social categories, and the emergence and development of new types of human relationships. Sociology was thus supposed to understand and then decipher the consequences of these processes, and to discern the nature of the new relationships. It was supposed to provide solutions to overcome the regime's problems and impasses. So- 
ciology was thus endowed with a functional role (or an operational function); the major themes around which the discipline revived were, in fact, the regime's problems, malfunctions, and failures. Although officially the thematic area of the re-emerging sociology included a variety of topics and concerns (theoretical approaches, the history of sociological doctrines, historical sociology, the methodology of sociological investigations, etc.), in reality it was mainly circumscribed to social realities (e.g., problems, malfunctions). Thus, great attention was paid to social phenomena and processes caused and/or influenced by the general and major policies (social, economic) of the regime. Sociological research focused on studies, investigations, and analyses of sub-systems - some of which were emergent, and with features and characteristics that required analyses for their efficient inclusion within the ultra-centralised macro-system (Costea et al. 2006: 371). The main topics of research were thus related to the industrialisation and urbanisation processes, and the collectivisation of agriculture - phenomena that led to a deep restructuring of Romanian society. Sociological research also covered issues related to the social and political implications of industrialisation and urbanisation, population dynamics (the exodus from rural to urban areas), the management of production, labour productivity, community life, workers' time budgets, and so forth (Constantinescu et al. 1974: 172-180). In addition, sociological investigation gave special attention to subjects related to the sociology of family, the sociology of populations (demography, health and hygiene studies), the sociology of youth (a very important theme in Romanian sociology, as a Research Centre for Youth Problems was founded in Bucharest and subordinated to the Ministry of Youth Affairs), the sociology of education, the sociology of culture, and the sociology of public opinion. Furthermore, problems limited to political practice - for instance, the sociology of mass organisations, the sociology of political propaganda, and the sociology of mass communication - also garnered considerable interest (Constantinescu 1971: 213-215).

These themes received more or less extensive study, which was financed by the state - proving that the regime acknowledged itself to be at an impasse. The type of disciplinary progress aimed at by sociology rarely went beyond empirical enquiries, focusing mainly on data collection and analysis. This tendency towards "technicality" and the cautious manner in which the sociological studies approached the regime's malfunctions were influenced by the complex relationship established between the academic field and the regime. While the re-emergence of sociology was a process that was prompted both from above and below - implying a cautious and 
meticulous negotiation between the two sides, the subsequent evolution of the field continued in a similar pattern. Although the regime tried to subordinate and control the production of knowledge, the academic field permanently claimed its autonomy and self-rule, attempting to meet not only the political demands, but also the requirements of scholarship. This intricate relation between the two sides, which was characterised by the regime's claim to control and the academic field's attempts at autonomy, generated specific tensions between the professionals and the political decision-makers, and determined the discipline's gradual but inevitable decline.

\section{/// Conclusions}

The history of Romanian sociology during the communist regime is hard to explain. In the early post-war years, the new political regime had a hostile attitude towards sociology, considering it a "bourgeois pseudo-science of society." Thus sociology was banned for almost two decades. A significant political, ideological, and intellectual breakthrough occurred only in the late 1950s and early 1960s. The re-institutionalisation of sociology occurred in the mid-1960s, and led to an explosion of empirical studies, followed by a significant increase in sociological literature. But the discipline began to decline again in the second half of the 1970s. Even if sociology was never banned again, after 1977 it was a marginalised social science. In reality, the "golden age" of Romanian sociology during socialism lasted for just one decade. Within this time frame, the history of sociology was tumultuous, frenetic, and eventful. Still, the major difficulties in understanding this history lie in the difference between what was supposed to happen (or what sociology was supposed to become), and what really happened (what sociology really became).

The official discourse advocated certain ideas as facts, as follows:

a) Romanian sociology was re-institutionalised out of necessity "the actual requirements of socialist society, and the need for a complete and multilateral knowledge of socialist reality" - as the regime tried to find explanations and solutions for the major reconfiguration society experienced during the first two decades of communist rule.

b) The resurgent sociology was supposed to develop itself detached from its interwar traditions, and the theoretical framework the discipline was supposed to fit was represented by Marxist philosophy. 
c) Sociology was assigned an important role within communist society, as it was requested to provide the regime with solutions for the country's malfunctions. Besides the descriptive and analytical functions of the discipline, sociology was imagined to be capable of developing itself as social engineering. It was supposed to elaborate predictions and prognoses on the major social, economic, and cultural policies of the regime.

d) Sociology was supposed to provide the data and the means for a new cycle of modernisation.

The reality was rather different:

a) Romanian sociology was in fact re-institutionalised out of necessity, but the primary aims involved nothing more than establishing scholarly relations with the Western countries. The subsequent evolution of the discipline was also due to inertia - as paradoxical as this may seem - as sociology was largely influenced by external developments in the field.

b) Romanian sociology never developed as a Marxist sociology, and often only formally accepted Marxist canons. This fact influenced its technical character, and the preference for empirical studies and research.

c) Sociology was never fully accepted by the decision-makers as a science capable of offering solutions to the regime's malfunctions. When (and if) solutions were requested, they were regarded with caution, and sometimes with suspicion by the decision-makers. To a certain degree, Romanian sociology retained obsolete ways of perceiving and defining the discipline, which was rather understood in terms of a social philosophy and not as capable of developing as an instrument of social engineering. The sociology curriculum was designed to train sociologists (with a major emphasis on philosophy) and not social engineers.

d) The short time frame of its re-institutionalisation (a decade) never allowed sociology to develop a legitimate discourse on modernisation.

Bibliography:

/// Bădina O. 1970a. "Research Center for Youth Problems - Bucharest," The Romanian Journal of Sociology, vol. 6, pp. 63-71. 
/// Bădina O. 1970b. "Le cadre institutionnel de l'étude scientifique de la jeunesse en Roumanie," Revue roumaine des sciences sociales: Série de sociologie, vol. 14, pp. 97-108.

/// Bărbat Al. 1970. "Sociological Activity Carried on by the Department of Economy of Agriculture and Statistics at the 'Al. I. Cuza' University, Iassy," The Romanian Journal of Sociology, vol. 6, pp. 127-129.

/// Batygin G.S., Deviatko I.F. 1994. “The Metamorphoses of Russian Sociology," [in:] Eastern Europe in Transformation: The Impact on Sociology, eds. M.F. Keen, J. Mucha, Greenwood Press, pp. 11-23.

/// Boia L. 2011. Capcanele istoriei. Elita intelectuală românească intre 1930-1950 [The Pitfalls of History: The Romanian Intellectual Elite between 19301950], Humanitas.

/// Bosomitu Ș. 2015. Miron Constantinescu. O biografie [Miron Constantinescu: A Biography], Humanitas.

/// Bugnariu T., Herseni T. 1964. "Școala sociologică de la București” [Bucharest Sociological School], Contemporanul, vol. 42(940), p. 7.

I/ Buletinul Oficial. "Decree no. 121/March 18, 1970 regarding the founding of the SRR's Academy of Social and Political Sciences," Buletinul Oficial, Year VI, no. 22, Part I, 18 March 1970.

/// Buzărnescu Ș., Chelcea S., Dungaciu D., Larionescu M., Măgureanu V., Rostaș Z., Schifirneț C. 2005. "Sociologia în România: trecut, prezent, perspective" [Romanian Sociology: Past, Present, Perspectives], Sociologie românească, vol. 3, pp. 5-37.

/// Cernea M. 1970. "Sociological Investigations Carried Out by the Institute of Philosophy," The Romanian Journal of Sociology, vol. 6, pp. 45-62.

/// Constantinescu M. 1970. "A General Survey of Romanian Sociology," The Romanian Journal of Sociology, vol. 4, pp. 7-13.

/// Constantinescu M. 1971. Cercetări sociologice, 1938-1971 [Sociological Surveys, 1938-1971], Editura Academiei RSR.

/// Constantinescu M. 1972. "Rolul actual al sociologiei româneşti. Contribuție la studiul realității sociale, elaborarea deciziilor social-politice" [The Current Role of Romanian Sociology: Contributions to the Study of Social Reality, and Socio-Political Decision- Making], Era socialistă, vol. 52, pp. ${ }^{9-10 .}$ 
/// Constantinescu M., Bădina O., Gall E. 1974. Sociological Thought in Romania, transl. S. Brucan, Meridiane Publishing House.

/// Costea S,., Cristea I., Dumitrescu D., Larionescu M., Stanciu L., Tănăsescu F. 2006. Istoria sociologiei românești [The History of Romanian Sociology], Editura Fundației România de Mâine.

/// Cotoi C. 2011. “Jottings on the History of Romanian Sociology," Studia UBB: Sociologia, vol. 56(1), pp. 135-149.

/// Kallós N., Roth A. 1970. "Achievements and Prospects in the Activity of the Sociological Laboratory of the 'Babes-Bolyai' University, Cluj," The Romanian Journal of Sociology, vol. 6, pp. 123-125.

/// Keen M.F., Mucha J. 1994. "Eastern Europe and Its Sociology," [in:] Eastern Europe in Transformation: The Impact on Sociology, eds. M.F. Keen, J. Mucha, Greenwood Press, pp. 1-10.

/// Kolaja J. 1974. "Notes on the Romanian Sociology," Acta Sociologica, vol. 17, pp. $78-82$.

/// Mespoulet M. 2007. "Quelle sociologie derrière le 'rideau de fer'?," Revue d'histoire des sciences humaines, vol. 16, pp. 3-10.

/// Mihăilescu I., Rostas Z. 2007. Dialog neterminat [Unfinished Dialogue], CurteaVeche.

/// Momoc A. 2012. Capcanele politice ale sociologiei interbelice. S,coala gustiana intre carlism și legionarism [The Political Pitfalls of Interwar Sociology: Gusti’s School between "Carlism" and "Legionarism"], CurteaVeche.

/// Rostas Z., Stahl H.H. 2000. Monografia ca utopie. Interviuri cu Henri H. Stabl [Monography as Utopia: Conversations with Henri H. Stahl], Paideia.

/// Schifirneț C. 1999. “Treizeci de ani de cercetare științifică a tineretului. Centrul de studii și cercetări pentru problemele tineretului” [Thirty Years of Scientific Research on Youth: The Centre for Studies and Research on Youth Problems], Sociologie românescă, vol. 1, pp. 137-142.

/// Shalin D. 1978. "The Development of Soviet Sociology, 1956-1976," Annual Review of Sociology, vol. 4, pp. 171-191.

/// Szmatka J., Wysienska K. 2000. "Polish and Eastern European Sociology," [in:] Encyclopedia of Sociology, eds. E.F. Borgatta, R.F.J. Montgomery, vol. 3, Macmillan, pp. 2116-2123. 
/// Sztompka P. 2004. "La condition de la sociologie en Europe centrale et orientale," [in:] Post-communisme: les sciences sociales à l'épreuve, eds. M. Forest, G. Mink, L’Harmattan, pp. 159-174.

/// T.B. 1962. "Activities of the National Sociological Committee," [in:] The Romanian Journal of Sociology, vol. 1, pp. 225-229.

/// Tismăneanu V. 2004. "Criza sociologiei românești” [The Crisis of the Romanian Sociology], [in:] V. Tismăneanu, Scopul și mijloacele. Eseuri despre ideologie, tiranie și mit [The Purpose and the Means: Essays on Ideology, Tyranny, and Myth], CurteaVeche, pp. 159-172.

/// Voříšek M. 2008. "Antagonist, Type, or Deviation? A Comparative View on Sociology in Post-War Soviet Europe," Revue d'bistoire des sciences humaines, vol. 18, pp. 85-113.

/// Verdery K. 1991. National Ideology under Socialism: Identity and Cultural Politics in Ceausescu's Romania, University of California Press.

/// Weinberg E.A. 2004. Sociology in the Soviet Union and Beyond: Social Enquiry and Social Change, Ashgate.

/// Wiatr J.J. 1971. "Status and Prospects of Sociology in Eastern Europe: A Trend Report," [in:] J.J. Wiatr, The State of Sociology in Eastern Europe Today, Southern Illinois University Press, pp. 1-19.

/// Zamfir C. 2005. "9 ipoteze pentru o analiză sociologico-epistemologică a sociologiei românești în perioada comunistă" [Nine Hypotheses for a Sociologic-Epistemological Analysis of Romanian Sociology during Communism], Sociologie românească, vol. 3(1), pp. 53-71.

/// Zamfir C. 2009. O istorie subiectivă în sociologia românească: din 1944 până in prezent [A Subjective History of the Romanian Sociology: from 1944 to Present Times], Polirom.

/// Zemtsov I. 1986. Soviet Sociology: A Study of Lost Illusion in Russia under Soviet Control of Society, Hero Books.

Archival materials:

/// National Archives of Romania, Council of Ministers fonds, section Athanase Joja Cabinet, file 15/1959, p. 6: "Address from the Central Committee's Internal Affairs Section.” 
/// National Archives of Romania, Council of Ministers fonds, section Athanase Joja Cabinet, file 15/1959, pp. 7-8: "Statute of the People's Republic of Romania National Sociological Committee."

/// National Archives of Romania, Central Committee of the Romanian Communist Party fonds, section Agitprop, file 9/1963, pp. 35-37: "Protocol of the Central Committee's Science and Art Section Meeting, 4 November 1963."

\section{/// Abstract}

The post-war history of Romanian sociology followed a tortuous path, similar to the evolutions within other countries of the Soviet Bloc. Defined as a "bourgeois" and "reactionary" social science, sociology was purged from the academic field for almost two decades. Its subsequent re-institutionalisation in the mid-1960s was a process largely influenced by social evolution in Romania (industrialisation, urbanisation, and the collectivisation of agriculture), but also by the desire to re-connect the Romanian social sciences to the international field of dialogue and debates. My paper discusses not only the institutional articulation and development of sociology in communist Romania, but also how the discipline was re-imagined and re-contextualised by the regime.

Keywords:

communist Romania, history of sociology, sociology versus ideology

/// Stefan Bosomitu - senior researcher (since 2007) at the Institute for the Investigation of Communist Crimes and the Memory of the Romanian Exile (Bucharest, Romania). Ph.D. in history (2011) from the University of Iași (Romania). Main fields of interest: the history of interwar communist movements, the history of post-war European communist regimes, intellectuals and communist regimes, and the social sciences under communism. Author of Miron Constantinescu. O biografie [Miron Constantinescu: A Biography] (2015).

Email: stefan.bosomitu@gmail.com 
